\title{
Caspase-dependent and -independent T-cell death pathways in pathogenic simian immunodeficiency virus infection: relationship to disease progression
}

\author{
D Arnoult ${ }^{1,4}$, F Petit $^{1,4}$, JD Lelièvie ${ }^{1}$, D Lecossier ${ }^{2}$, A Hance $^{2}$, \\ V Monceaux ${ }^{3}$, R Ho Tsong Fang ${ }^{3}$, B Huntrel ${ }^{3}$, JC Ameisen ${ }^{1}$ and \\ J Estaquier ${ }^{*, 3}$ \\ 1 INSERM EMI-U 9922, Faculté Bichat-Claude Bernard, Paris, France \\ 2 INSERM U82, Faculté Bichat-Claude Bernard, Paris, France \\ ${ }^{3}$ Unité Physiopathologie des Infections Lentivirales, Institut Pasteur, Paris, \\ France \\ ${ }^{4} \mathrm{D}$ Arnoult and F Petit contributed to this work equally. \\ * Corresponding author: J Estaquier, Institut Pasteur, Unité Physiopathologie \\ des Infections Lentivirales, 28 rue du Dr Roux, 75724 Paris cedex 15, France. \\ Tel: + 33-1-45-68-89-15; Fax: + 33-1-40-61-34-50; \\ E-mail: jestaqui@pasteur.fr
}

Received 24.10.02; revised 25.3.03; accepted 20.5.03

Edited by Dr Green

\begin{abstract}
Studies of human immunodeficiency virus (HIV) and nonhuman primate models of pathogenic and nonpathogenic simian immunodeficiency virus (SIV) infections have suggested that enhanced ex vivo CD4 T-cell death is a feature of pathogenic infection in vivo. However, the relative contributions of the extrinsic and intrinsic pathways to programmed T-cell death in SIV infection have not been studied. We report here that the spontaneous death rate of CD4 $+\mathrm{T}$ cells from pathogenic SIVmac251-infected rhesus macaques ex vivo is correlated with CD4 T-cell depletion and plasma viral load in vivo. CD4 $+\mathrm{T}$ cells from SIVmac251-infected macaques showed upregulation of the death ligand (CD95L) and of the proapoptotic proteins Bim and Bak, but not of Bax. Both CD4 + and CD8 + T cells from SIVmac251-infected macaques underwent caspase-dependent death following CD95 ligation. The spontaneous death of CD4 + and CD8 + T cells was not prevented by a decoy CD95 receptor or by a broad-spectrum caspase inhibitor (ZVADfmk), suggesting that this form of cell death is independent of CD95/CD95L interaction and caspase activation. IL-2 and IL-15 prevented the spontaneous death of CD4 + and CD8 + T cells, whereas IL-10 prevented only CD8 T-cell death and IL-7 had no effect on T-cell death. Our results indicate that caspasedependent and caspase-independent pathways are involved in the death of T cells in pathogenic SIVmac251-infected primates. Cell Death and Differentiation (2003) 10, 1240-1252. doi:10.1038/ sj.cdd. 4401289
\end{abstract}

Keywords: AIDS; SIV; apoptosis; caspases; cytokines; mitochondria; CD95; Bim; Bak

Abbreviations: HIV, human immunodeficiency virus; mAb, monoclonal antibody; PBMC, peripheral blood mononuclear cells; SIV, simian immunodeficiency virus

\section{Introduction}

HIV-1 infection leads to CD4 T-cell depletion associated with high rates of viral turnover, ${ }^{1}$ preceded by a progressive loss of T-cell-mediated immunity. ${ }^{2}$ T-cell apoptosis is thought to be one of the mechanisms responsible for $\mathrm{T}$-cell depletion during HIV and SIV infections. Several studies have found that uninfected CD4 + and CD8 + T cells from HIV-1-infected individuals display abnormal levels of apoptosis, both in vitro and in vivo. Furthermore, studies performed in primate models of pathogenic and nonpathogenic HIV or SIV infection have identified a correlation between the induction of an increase in the rate of T-cell apoptosis in vitro and the pathogenic nature of the retroviral infection in vivo., $\mathrm{An}$ increase in CD4 T-cell apoptosis was observed only in models leading to AIDS or similar syndromes: HIV-1-infected human individuals, rhesus macaques infected with a pathogenic strain of SIVmac, and chimpanzees infected with a pathogenic strain of HIVLAV-1b. In contrast, an increase in CD8 Tcell apoptosis was observed in both pathogenic and nonpathogenic models of infection in primates. The increase in the rate of T-cell apoptosis in HIV-infected human individuals is associated with an increase in expression of the CD95 receptor and its ligand (CD95L), and an increase in the sensitivity of $\mathrm{T}$ cells to apoptosis mediated by CD95 ligation, using either agonistic CD95 monoclonal antibodies (mAb) or recombinant CD95L. ${ }^{4}$ Other members of the TNF-receptor ligand family (TRAIL, TNF- $\alpha$ ) have also been implicated in the increase in T-cell apoptosis seen in HIV-1-infected individuals. ${ }^{4,5}$ However, it is unclear whether the level of T-cell apoptosis is correlated with either viral load or progression to AIDS. $^{6-8}$

Two pathways are known to be important in the transduction of death signals to the apoptotic machinery. The 'extrinsic' pathway involves death receptors and activation of the caspase cascade. 9,10 The 'intrinsic' pathway is death receptor-independent. In the intrinsic pathway, multiple stimuli, such as stress, drugs, and survival factor deprivation, induce a cell death programme that may be caspase-dependent or independent. When involved in the cell death programme, caspases are required only for induction of the nuclear apoptotic phenotype. ${ }^{10,11}$ Stimuli activating the intrinsic pathway converge on the mitochondrial sensor, inducing the release of proapoptotic factors, leading to apoptosis. ${ }^{12,13}$

The apoptosis induced by HIV and SIV may involve dysregulation of the intrinsic pathway. Members of the $\mathrm{Bcl}-2$ protein family play a critical role in controlling the permeabilisation of the outer mitochondrial membrane. ${ }^{12-14}$ Previous studies of apoptosis in syncytia ${ }^{15,16}$ and cells productively infected with HIV-1 ${ }^{17-19}$ have shown an increase in Bax levels and a loss of mitochondrial membrane potential due to mitochondrial permeabilisation. However, the overproduction of Bax has not been clearly demonstrated during natural HIV 
infection and remains a matter of debate. ${ }^{20,21}$ Despite the considerable effort directed at elucidating the mechanisms responsible for apoptosis in HIV-1 infection in humans, very little information has been obtained from primate models of lentivirus infection and the available data principally concern the acute phase..$^{22-24}$ In particular, no study has addressed the question of the relative contributions made by the extrinsic and intrinsic pathways to programmed T-cell death during SIV infection. In addition, no attempt has been made to evaluate the correlation between disease progression and the probability of $\mathrm{T}$ cells undergoing apoptosis after CD95 ligation. Moreover, the results obtained by $\mathrm{Xu}$ et al. $^{25}$ are not unequivocal as the $\mathrm{mAbs}$ used were inappropriate for primate models. ${ }^{26}$

This study therefore had two main aims. First, we sought to determine whether differences in the rates of $\mathrm{T}$-cell apoptosis in models of pathogenic and nonpathogenic infections in primates could be accounted for by differences in the expression of CD95 or its ligand (CD95L) and/or by differences in signal transduction induced by CD95 ligation. Second, we aimed to identify the main components of the death machinery involved in progressive CD4 T-cell depletion. We found that CD4 + and CD8 $+\mathrm{T}$ cells from macaques infected with the pathogenic SIVmac251 strain were more likely to undergo apoptosis following CD95 ligation, and that this process involved a caspase-dependent pathway. However, we also demonstrated that the rate of spontaneous CD4 T-cell death in vitro has predictive value concerning the likelihood of progression to AIDS, and that such cell death occurs independent of CD95/CD95L interactions or caspase activation. Both CD95-dependent and -independent cell death programmes led to a loss of mitochondrial membrane potential. This loss of membrane potential was not associated with Bax upregulation, but was associated with upregulation of the proapoptotic proteins Bak and Bim.

\section{Results}

\section{Apoptosis in pathogenic SIV-infected macaques is correlated with CD4 T-cell depletion and viral load}

At 1-3 years after infection with SIVmac251, rhesus macaques develop a disease remarkably similar to AIDS in HIV-1-infected humans. Infection with SIVmac251 led to a significant depletion of CD4 + T cells (Figure 1a), whereas no such depletion was observed in animals infected with a SIVmac clone from which the nef gene had been depleted ( $\Delta$ nef), which did not induce disease. ${ }^{27}$ An increase in the proportion of activated circulating CD4 + and CD8 + T cells (Figure 1b) and impairment of the proliferation of $\mathrm{T}$ cells directed against HIV-2 antigens (Figure 1c) were also observed in animals infected with SIVmac251, but not in those infected with the $\Delta$ nef virus.

Spontaneous T-cell death during an $18 \mathrm{~h}$ period of culture was quantified by flow cytometry, for cells from uninfected rhesus macaques (SIV-) and cells from animals infected with the pathogenic SIVmac251 strain or the $\Delta$ nef strain. The rate of T-cell death was significantly higher in SIVmac251-infected animals than in uninfected animals and animals infected with the $\Delta$ nef strain, although some variability was observed
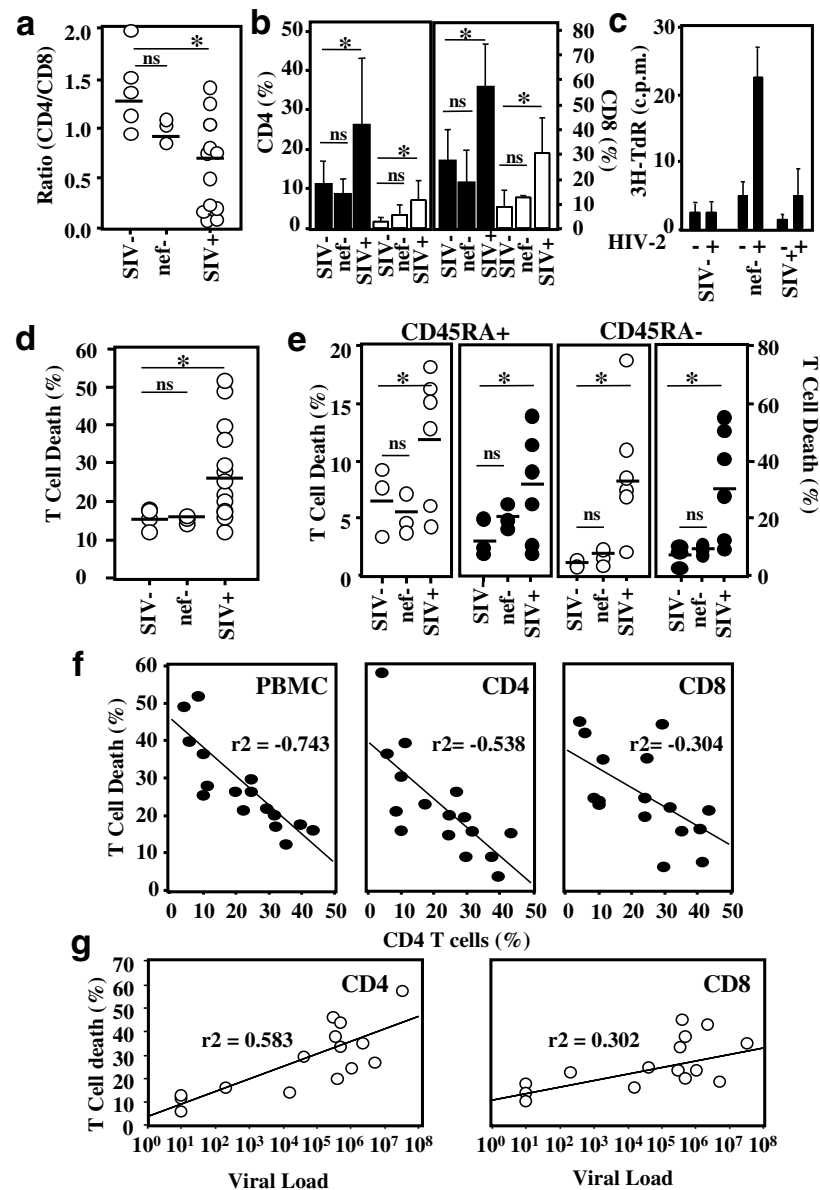

Figure 1 Higher rates of T-cell death are associated with pathogenic SIV infection and progressive CD4 T-cell depletion. (a) CD4/CD8 T-cell ratio of uninfected macaques (SIV-), and macaques infected with the nef-deleted SIVmac251 clone (nef-) or the SIVmac251 strain (SIV +). Each circle represents the results from one individual. (b) Proportions of $\mathrm{CD} 4+$ and CD8 + T cells expressing HLA-DR $(\boldsymbol{\square})$ and CD69 ( $\square$ ). Data are means \pm S.D. of five uninfected macaques (SIV-), four macaques infected with the nef-deleted SIVmac251 clone (nef-), and nine macaques infected with the SIVmac251 strain $(\mathrm{SIV}+)$. (c) T-cell proliferation plotted against HIV-2 antigens $(1 \mu \mathrm{g} / \mathrm{ml})$. Data are the mean \pm S.D. of four individual animals tested in each group. (d) T-cell death in PBMC was determined by flow cytometry, using acridine orange nuclear stain. Each circle represents the results from one individual. (e) Death of naive (CD45RA + ) and memory (CD45RA-) subsets of CD4 + (O) and CD8 + (0) $\mathrm{T}$ cells. Each circle represents the results from one individual. (f) Correlation between the death rates in vitro of PBMC, $\mathrm{CD} 4+$ and $\mathrm{CD} 8+, \mathrm{T}$ cells from macaques infected with the SIVmac251 strain and the in vivo percentages of $\mathrm{CD} 4+\mathrm{T}$ cells. Each circle represents the results from one individual. The correlation coefficient ( $\mathrm{r} 2$ ) was determined by linear regression. (g) Correlation between the rate of cell death in vitro for $\mathrm{CD} 4+$ and $\mathrm{CD} 8+\mathrm{T}$ cells from macaques infected with the SIVmac251 strain and plasma viral load. Each circle represents the results from one individual. The correlation coefficient (r2) was determined by linear regression. Statistical significance was assessed using Student's $t$-test. ( ${ }^{*} P<0.05$; ns: not significant)

(Figure 1d). The CD45RA + and CDR45RA- subsets of CD4 + and CD8 + T cells from pathogenic SIVmac251infected animals were more likely to undergo apoptosis in vitro than were other cells (Figure 1e). Two factors were identified that contributed to variation between individual SIVmac251infected animals in terms of spontaneous T-cell death. 
The percentage of PBMC, CD4 +, and CD8 + T cells that died was negatively correlated with the percentage of circulating CD4 $+\mathrm{T}$ cells (Figure 1f), but not with the percentage of circulating CD8 $+\mathrm{T}$ cells (data not shown). As in SIV infection, the proportion of HIV-infected individuals with rates of spontaneous $\mathrm{T}$-cell death higher than those observed for $T$ cells from uninfected individuals was inversely related to total CD4 T-cell counts (data not shown). We also observed that CD8 + T-cell counts fell dramatically when CD4 $\mathrm{T}$-cell numbers decreased in vivo at the onset of the AIDS-like syndrome in SIVmac251-infected macaques (data not shown). The proportion of purified CD8 $+\mathrm{T}$ cells dying ex vivo was higher $(38 \pm 8 \%)$ than the proportion of PBMC that died ( $26 \pm 7 \%)$, suggesting that the presence of CD4 + T cells favours CD8 T-cell survival. These observations suggest that CD4 + T cells act as 'feeder cells' for CD8 + T cells and highlight the importance of environmental factors in the control of T-cell death. Our data also indicated that the rates of CD4 and CD8 T-cell death were positively correlated with plasma viral load (Figure $1 \mathrm{~g}$ ). Thus, our results indicate that the death ex vivo of T cells from macaques infected with the pathogenic SIVmac251 strain is correlated with the gradual decline of CD4 + T-cell counts in vivo and rates of viral replication - two major prognostic factors for progression to AIDS.

\section{Increase in susceptibility to CD95-mediated apoptosis in macaques infected with pathogenic SIV}

We evaluated CD95 mRNA levels in freshly isolated PBMC from macaques infected with SIVmac251 or $\Delta$ nef virus and from uninfected animals by quantitative RT-PCR; CD95 mRNA levels were similar in these three groups (Figure 2a). We assessed CD95 expression on T cells by flow cytometry with the DX2 mAb. The proportion of CD4 + and CD8 + T cells expressing CD95 did not differ significantly in the three groups. However, the mean percentage of CD4 + (54 $\pm 11 \%)$ and CD8 $+\mathrm{T}$ cells $(77 \pm 6 \%)$ from animals infected with SIVmac251, which expressed CD95 was slightly higher than that for control animals (CD4 + : 46 $\pm 11 \%$; CD8 + : $69 \pm 10 \%$ ) (Figure 2b). The proportion of CD4 + T cells expressing CD95 was higher for HIV-infected humans than for uninfected individuals ( $69 \pm 26$ and $33 \pm 8 \%$, respectively). Furthermore, the proportion of CD4 + T cells expressing CD95 in HIV-1infected chimpanzees did not differ significantly from that for uninfected chimpanzees $(27 \pm 14$ and $31 \pm 14 \%$, respectively), and was in the same range as that for CD4 $+\mathrm{T}$ cells from healthy humans (data not shown). A higher proportion of $\mathrm{CD} 8+\mathrm{T}$ cells from HIV-infected humans than from healthy donors expressed CD95 ( $70 \pm 20$ and $28 \pm 10 \%$, respectively). The proportion of chimpanzee CD8 $+\mathrm{T}$ cells expressing CD95 was variable, but did not differ significantly between HIV-infected and -uninfected animals $(52 \pm 15$ and $39 \pm 22 \%$, respectively; data not shown).

Not all $\mathrm{T}$ cells expressing CD95 undergo apoptosis following stimulation by the cognate ligand. ${ }^{28-31}$ As the antibodies classically used to assess CD95 sensitivity in humans do not crossreact with macaque $\operatorname{CD95}^{24}$ (data not
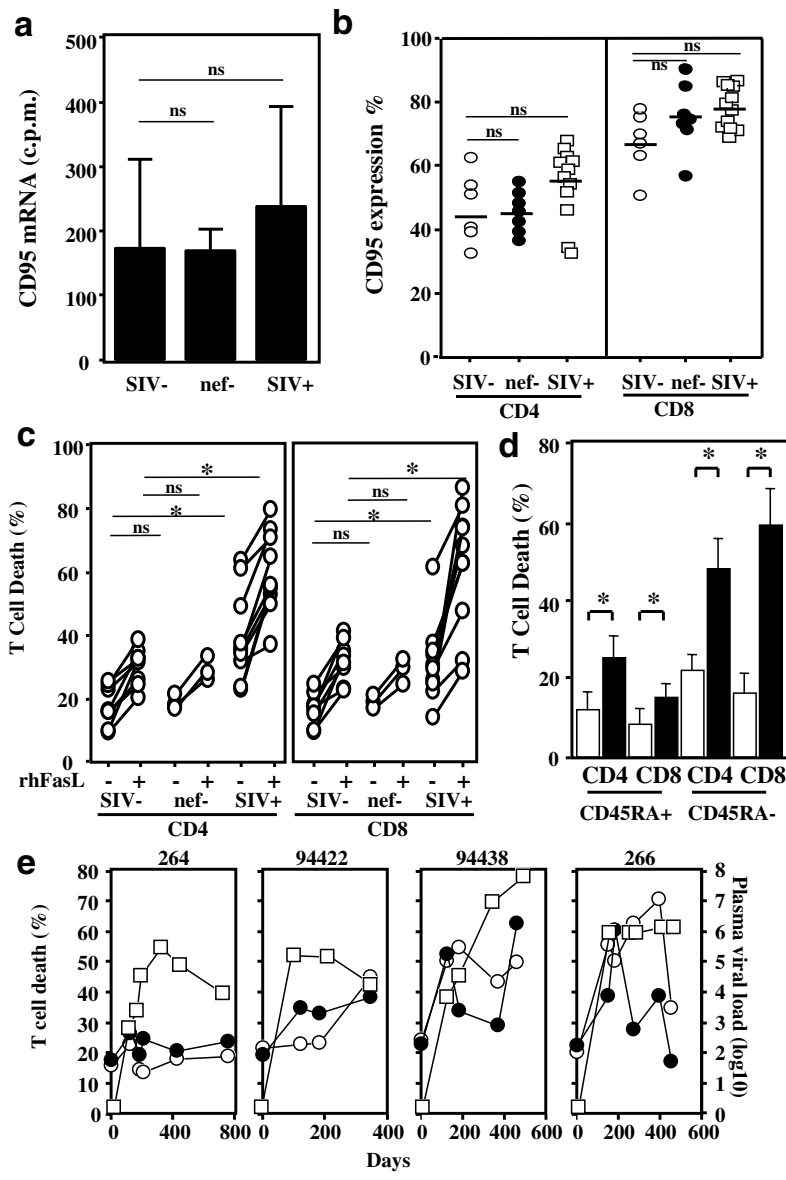

Figure 2 CD95 expression and susceptibility to CD95 ligation-mediated cell death in T cells from SIV-infected macaques. (a) CD95 mRNA levels in PBMC from uninfected macaques (SIV-), and macaques infected with the nef-deleted SIVmac251 clone (nef-) or the SIVmac251 strain (SIV+). Data are the means \pm S.D. of four individual macaques. (b) Expression of the CD95 molecule on CD4 + and CD8 + T cells. Each symbol represents the results from one individual. (c) CD95-mediated T-cell death was assessed in the absence (-) or presence $(+)$ of rhCD95L $(400 \mathrm{ng} / \mathrm{ml})$. Each circle represents the results from one individual. (d) Proportion of the CD45RA + and CD45RA- T-cell subsets primed for apoptosis following CD95 ligation. Data are the means \pm S.D. of four and five individual animals uninfected $(\square)$ and infected with SIVmac251 (ם), respectively. (e) Longitudinal analysis of CD95 ligation-mediated CD4 (O) and CD8 (O) T-cell death as a function of plasma viral load ( $\square$ ) in four individual SIVmac251-infected monkeys. Statistical significance was assessed using Student's $t$-test ( ${ }^{*} P<0.05$; ns: not significant)

shown), we used human recombinant soluble CD95L to evaluate the likelihood of $\mathrm{T}$ cells undergoing apoptosis after CD95 ligation. The incubation of CD4 + and CD8 + T cells from SIVmac251-infected animals with soluble CD95L considerably increased the proportion of dead cells over that for cells incubated with medium alone. This increase in the rate of cell death was significantly greater than that observed for $T$ cells from uninfected animals and animals infected with the $\Delta$ nef strain (Figure 2c). Both the CD45RA + and CD45RA-Tcell subsets from SIVmac251-infected animals were more susceptible to death induced by CD95L (Figure 2d). However, CD45RA - T cells were more prone to spontaneous and CD95L-induced apoptosis than CD45RA + T cells. Although we found no difference in the proportion of $T$ cells expressing CD95, our results provide the first demonstration that $T$ cells 
from pathogenic SIVmac251-infected animals are more likely to undergo apoptosis in response to CD95-ligation during the chronic asymptomatic phase.

CD4 + and CD8 + T cells from HIV-infected humans are two to three times more susceptible to apoptosis than cells from uninfected individuals (data not shown). We performed similar experiments with $\mathrm{T}$ lymphocytes from chimpanzees and found that the levels of CD4 T-cell apoptosis induced by the agonistic CD95 mAb did not differ significantly for HIVinfected and uninfected animals (data not shown).

Thus, the results obtained for CD4 + and CD8 $+\mathrm{T}$ cells from SIVmac251-infected macaques are consistent with those obtained for cells from HIV-1-infected humans (increase in rates of spontaneous and CD95-induced cell death, inverse correlation between spontaneous apoptosis and $\mathrm{T}$ cell number). Although the percentage of $\mathrm{T}$ cells expressing CD95 increased in both virus-infected human and macaque $T$ cells, statistically significant differences were observed only for human cells. This may, at least in part, be due to the percentage of CD95-expressing T cells in uninfected macaques being considerably-higher than that in humans. Similarly, the results obtained for CD4 + T cells from HIV-infected chimpanzees, which do not develop an AIDS-like illness, were generally similar to those obtained for cells from macaques infected with the nonpathogenic $\Delta$ nef strain (no increase in spontaneous or CD95-induced apoptosis or CD95 expression).

Longitudinal analysis of CD95L-induced cell death was performed for four macaques, two of which were slow progressors (monkeys 264 and 94422), the other two being progressors (monkeys 266 and 94438). The rates of CD4+ and CD8 + T-cell death induced by CD95 ligation were higher in progressors than in slow progressors, as was viral load (Figure 2e). Nonetheless, no obvious one-to-one correlation between changes in viral load and changes in the susceptibility of CD4 + or CD8 + T cells to CD95L-induced apoptosis were apparent. For example, the rate of CD8 T-cell death decreased in monkey 266 between days 200 and 400 , whereas plasma viral load remained high $\left(>10^{6}\right.$ copies $/ \mathrm{ml}$ ) during this period. These data suggest that an abnormally high susceptibility of CD4 $+\mathrm{T}$ cells and CD8 $+\mathrm{T}$ cells to apoptosis induced by CD95 ligation is associated with pathogenic SIV infection and progression towards AIDS or an AIDS-like disease. They also suggest that viral load, although possibly important, is not the sole factor determining susceptibility to cell death via the CD95 pathway.

\section{Caspase activation is not essential for spontaneous T-cell death in pathogenic SIV-infected macaques}

Caspase activation is a key biochemical event in apoptosis. ${ }^{9,10}$ Flow cytometry with a fluorescent substrate (PhiPhiLux) showed that the level of caspase activity was higher in $\mathrm{T}$ cells from SIVmac251-infected macaques than in cells from uninfected macaques after overnight culture. This higher level of caspase activity was associated with increases in chromatin condensation and fragmentation, as assessed by acridine orange staining (Figure 3). a
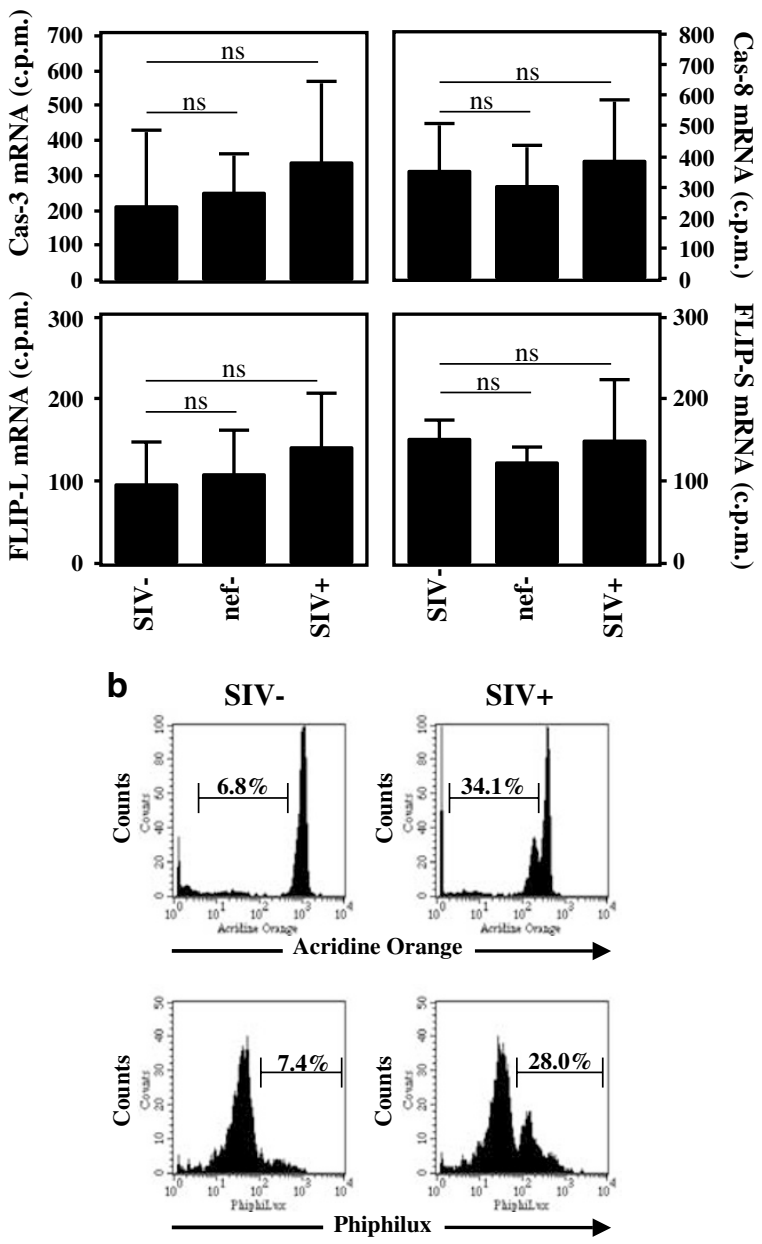

Figure 3 Caspase production and activity in PBMC from macaques. Chromatin condensation and fragmentation (assessed using acridine orange nuclear stain) and caspase activity (using Phiphilux as a fluorescent substrate for caspase) in PBMC of an uninfected (SIV-) and a SIVmac251-infected macaque (SIV +), cultured overnight in medium alone

We investigated whether the spontaneous death of CD4 + and CD8 + T cells from SIVmac251-infected macaques was prevented by either the broad-spectrum caspase inhibitor zVAD-fmk and/or cytokines. Preincubation of T cells from SIVinfected macaques for $30 \mathrm{~min}$ with zVAD-fmk prevented the death of both CD4 + and CD8 + T cells induced by rhCD95L (98 $\pm 35 \%$ of prevention). It also prevented the chromatin condensation and fragmentation characteristic of caspasedependent apoptosis (data not shown). FA-fmk, a cathepsin protease inhibitor, had no effect on cell death (data not shown). zVAD-fmk, which efficiently prevented CD95Linduced cell death, only slightly inhibited spontaneous cell death (less than 15\% inhibition; Figure 4). Despite this very weak effect on cell survival, zVAD-fmk inhibited chromatin condensation and fragmentation in the dying cells (by about $70 \%$, data not shown). IL-2 and IL-15 reduced the death rate of both CD4 + and CD8 + T cells, although these compounds generally had a greater effect on CD8 $+T$ cells than on CD4 + T cells. IL-10 had a significant preventive effect only on the spontaneous death of CD8 + T cells (Figure 4c). IL-7, a cytokine known to play a critical role in regulating $\mathrm{T}$-cell 

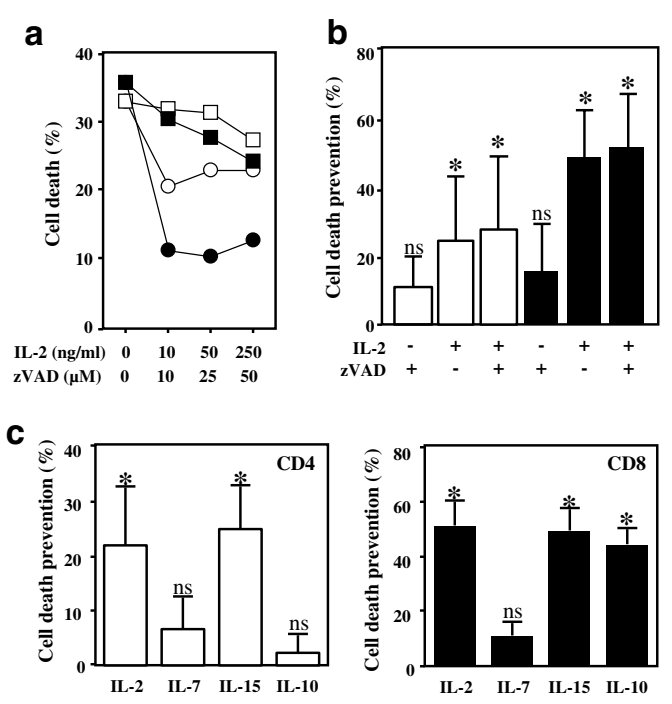

Figure 4 Modulation of spontaneous cell death in macaques infected with the pathogenic SIVmac251 strain. (a) $\operatorname{CD} 4(\square, \bigcirc)$ and $\operatorname{CD} 8(\mathbf{\square}, \mathbf{0})$ T-cell death in PBMC incubated with various concentrations of ZVAD-fmk (zVAD $(\square, \mathbf{\square}): 0,10$, 25 , and $50 \mu \mathrm{M})$ or IL-2 $(\bigcirc, 0 ; 0,10,50$, and $250 \mathrm{ng} / \mathrm{ml})$. (b) CD4 ( $\square)$ and CD8 (- ) T-cell death after incubation in the absence $(-)$ or presence $(+)$ of ZVADfmk $(50 \mu \mathrm{M})$ and/or IL-2 $(20 \mathrm{ng} / \mathrm{ml})$. The preventive effect was evaluated as follows: (1-(spontaneous cell death after treatment/spontaneous cell death) $) \times 100$. Data are means \pm S.D. of 12 individual macaques. Statistical significance was assessed using the paired Student's $t$-test $\left({ }^{*} P<0.05\right.$; ns: not significant). The preventive effects of ZVAD-fmk and IL-2 were compared with the effects of medium alone. (c) T cells were incubated in the presence of IL-2, IL-7, IL-10, or IL-15 $(20 \mathrm{ng} / \mathrm{ml})$. The preventive effect was determined as described in (b). Data are means \pm S.D. of five individual macaques. Statistical significance was assessed using the paired Student's $t$-test ( ${ }^{*} P<0.05$; ns: not significant) comparing cytokine pretreatment with medium alone

development, regeneration, and function, had no significant effect on the spontaneous death of CD4 + or CD8 $+\mathrm{T}$ cells (Figure 4c). A combination of IL-2 and zVAD-fmk was no more effective than IL-2 alone in preventing spontaneous cell death (Figure 4b).

Thus, in contrast to the essential role of caspase activation downstream from CD95 ligation, the activation of caspases involved in producing certain features of the apoptotic phenotype (chromatin condensation and fragmentation) is not essential for the spontaneous death of $T$ cells from SIVmac251-infected animals.

\section{Spontaneous death of T cells from SIVmac251- infected macaques is CD95/CD95L-independent}

The requirement of caspases for CD95-mediated T-cell death but not for spontaneous $\mathrm{T}$-cell death raises questions concerning the possible involvement of CD95/CD95L interactions in spontaneous T-cell death. CD95L expression has been reported to increase during $\mathrm{HIV}^{32-34}$ and SIV infections. ${ }^{35}$ CD95L mRNA levels were significantly higher in PBMC from macaques infected with SIVmac251 or $\Delta$ nef than in uninfected animals (Figure 5a). CD95L expression could not be unequivocally detected on macaques by flow cytometry with the antibodies currently available (data not shown). We therefore carried out Western blotting. T cells from SIVmac251-infected macaques expressed CD95L (35 kDa) more a
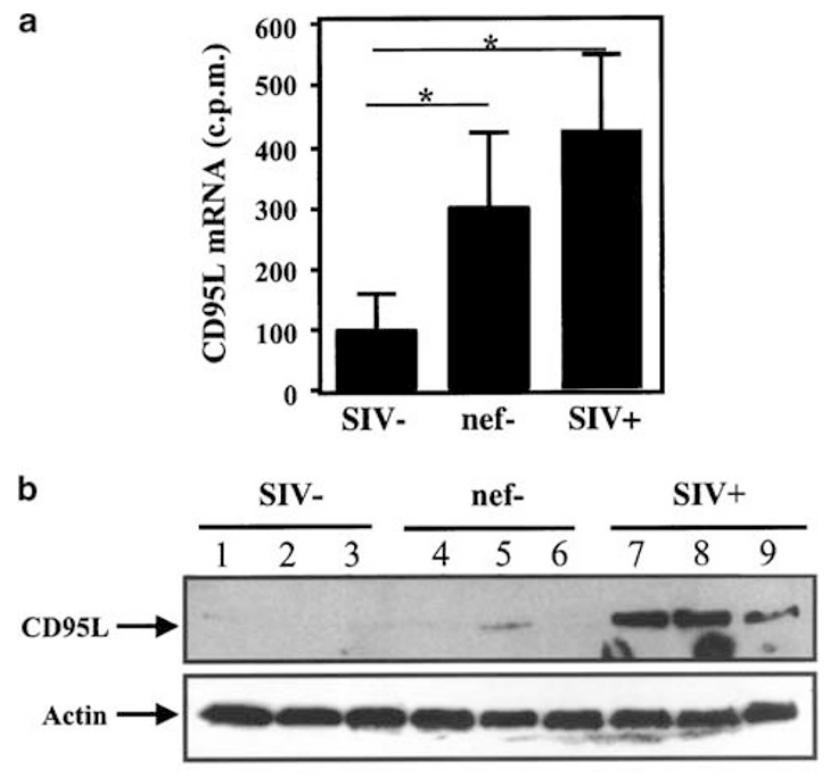

C

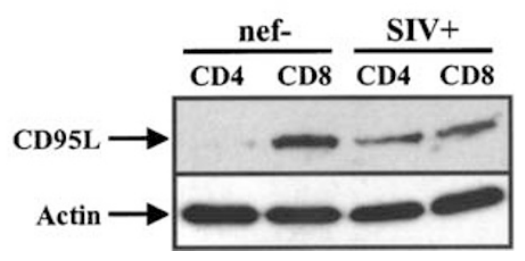

Figure 5 CD95 Lexpression in T cells from macaques. (a) CD95L mRNA levels were determined in freshly isolated PBMC from uninfected macaques (SIV-), and macaques infected with the nef-deleted SIVmac251 clone (nef-) or the SIVmac251 strain $($ SIV +$)$. Data are means \pm S.D. of four individual macaques. Statistical significance was assessed using Student's $t$-test (ns: not significant). (b) Western blots show CD95L ( $35 \mathrm{kDa}$ ) levels in PBMC from three individual macaques in each group. Actin was used as a control for loading. (c) Western blots show CD95L levels in CD4 + and CD8 $+T$ cells from macaques either infected with the nef-deleted SIVmac251 clone (nef-) or infected with the SIVmac251 strain (SIV + ). Actin was used as a control for loading

strongly than T cells from uninfected animals (Figure $5 \mathrm{~b}$ ), and CD4 + and CD8 + T cells were found to express CD95L to similar extents (Figure 5c). Lower levels of CD95L expression were observed on T cells from some of the macaques infected with $\Delta$ nef. However, for these animals, expression was stronger on CD8 + T cells than on CD4 + T cells.

We investigated whether CD95-Fc could prevent the spontaneous death of $T$ cells from SIVmac251-infected animals. T cells from pathogenic SIVmac251-infected macaques were more susceptible to apoptosis induced by CD95 ligation (Figure 2c) and expressed CD95L strongly (Figure $5 b, c)$. However, the CD95-Fc fusion protein had no major effect on the spontaneous cell death rate of CD4 + or CD8 + $\mathrm{T}$ cells (Figure 6 ). Thus, the death rate of CD4 + or CD8 $+\mathrm{T}$ cells cultured in the presence of CD95-Fc was not decreased by more than $15 \%$ with respect to cells maintained in medium alone, and no significant differences were observed in comparisons of treated and untreated cells.

Jurkat $T$ cells have been extensively used in studies of CD95L-mediated cell death, and they provide a means of assessing cytotoxicity independently of viral effects in the SIV model. ${ }^{36}$ We found that CD4 $+\mathrm{T}$ cells had no significant 


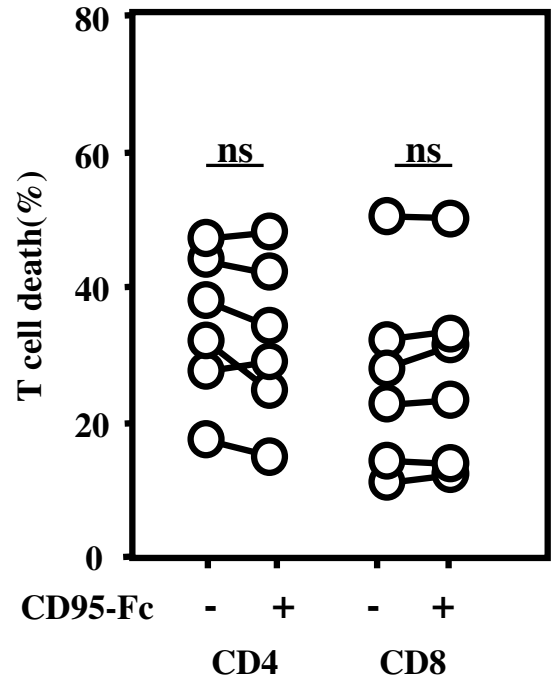

Figure 6 Functional assay for CD95L. PBMC from SIVmac251-infected macaques were incubated in the absence $(-)$ or presence $(+)$ of the CD95-Fc molecule $(10 \mu \mathrm{g} / \mathrm{ml})$. CD4 and CD8 T-cell death was assessed by two-colour flow cytometry. Each symbol represents one individual macaque. Statistical significance was assessed using the paired Student's t-test (ns: not significant)

cytotoxicity $(12 \pm 12 \%)$, with an ET ratio of $5 / 1$ with respect to soluble recombinant $\mathrm{CD} 95 \mathrm{~L}$, which, at a concentration of $20 \mathrm{ng} / \mathrm{ml}$, caused the death of $80 \%$ of cells cultured overnight (data not shown). Moreover, although Jurkat cells are extremely susceptible to cell death induced by CD95 engagement, an excess of soluble CD95-Fc fusion protein, which blocks CD95/CD95L interactions, had no effect on the cytotoxicity of CD4 + T cells (data not shown).

Thus, CD95L does not seem to be essential for the spontaneous death of $T$ cells from SIVmac251-infected animals.

\section{Spontaneous death of T cells from SIVmac251- infected macaques involves a loss of mitochondrial membrane potential associated with upregulation of Bim and Bak, but not of Bax}

We observed that the higher rate of spontaneous death of $T$ cells from SIVmac251-infected macaques was associated with a higher proportion of cells having high levels of phosphatidyl-serine (detected by staining with FITC-labelled annexin-V) and a decrease in $\Delta \psi \mathrm{m}$, as assessed with $\mathrm{DiOC}_{6}$ (Figure 7a). Two-colour flow cytometry, using $\mathrm{DiOC}_{6}$ and labelled anti-CD4/CD8 mAbs (Figure 7b), showed that a higher proportion of $\mathrm{CD} 4+$ and $\mathrm{CD} 8+\mathrm{T}$ cells from SIVmac251-infected macaques (SIV,$+ n=6)$ than from uninfected macaques (SIV-, $n=4$ ) displayed decreases in $\Delta \psi \mathrm{m}$.

Proapoptotic members of the Bcl-2 family have been reported to be crucial in the control of $\Delta \psi \mathrm{m}$ in various pathways leading to apoptosis, ${ }^{12,13}$ including that associated with HIV-1 infection. ${ }^{16-18}$ Levels of three proapoptotic proteins - Bak (30 kDa), Bax (23kDa), and BimL (25kDa) - were assessed by Western blotting with proteins from purified CD4 + and CD8 + T cells from SIVmac251-infected animals and uninfected controls (Figure 7c,d). The amount of Bax in CD4 + and CD8 + T cells was similar in cells from infected and uninfected macaques (with the exception of one of the six infected animals tested), whereas BimL and Bak protein levels were $30-50 \%$ higher in CD4 + and CD8 + T cells from SIVmac251-infected animals. These results are not consistent with Bax playing a major role in the loss of $\Delta \psi \mathrm{m}$ and subsequent cell death, but provide the first evidence that BimL and Bak may be involved in AIDS pathogenesis.

\section{Discussion}

Our results demonstrate an increase in susceptibility to apoptosis mediated by two different pathways in T cells from macaques infected with the virulent SIVmac251 strain, but not in $T$ cells from animals infected with the nonpathogenic SIVmac251- $\Delta$ nef strain. T cells from macaques infected with the pathogenic strain displayed higher levels of spontaneous apoptosis, which were positively correlated with both viral load and the extent of T-cell depletion. In addition, both CD4 + and CD8 $+\mathrm{T}$ cells from SIVmac251-infected animals demonstrate a marked increase in susceptibility to apoptosis induced by CD95 ligation. This is consistent with previous work indicating that peripheral blood $\mathrm{T}$ cells from HIV-infected individuals ${ }^{34,37-40}$ are more sensitive than those of controls to apoptosis induced by CD95 ligation. Although spontaneous apoptosis and CD95-induced apoptosis involved caspase activation and changes in mitochondrial permeability, different intracellular signalling pathways seemed to be involved in these two processes. The incubation of $\mathrm{T}$ cells from SIVmac251-infected macaques with a CD95-Fc fusion protein did not inhibit spontaneous apoptosis. This suggests that signalling through CD95 is not involved in this process, but does not exclude the possibility that the cells had already received a lethal signal via CD95 in vivo. Consistent with these results, McCloskey et al. ${ }^{41}$ found that the T cells from HIVinfected children who underwent spontaneous apoptosis were mostly CD95-negative. We also found that the spontaneous death of $T$ cells from pathogenic SIVmac251-infected macaques was not prevented by the broad-spectrum caspase inhibitor, zVAD-fmk, despite the inhibitory effects of this molecule on chromatin condensation and fragmentation in the dying cells and its prevention of cell death due to CD95 ligation. Thus, caspase activation occurred during spontaneous apoptosis, not essential for cell death, as described in other cell types. ${ }^{17,42-46}$

The mechanisms responsible for spontaneous apoptosis are unclear. In particular, it remains a matter of debate whether other members of the TNF receptor family are involved. Some studies have suggested a role for TRAIL, ${ }^{47-49}$ TNF-R1 and TNF-R2, 5,50 whereas others reported that the engagement of these receptors did not increase the rate of $\mathrm{T}$ cell death above the spontaneous rate. ${ }^{39,51,52}$ In contrast to the results obtained with crosslinked CD95L, we found that the crosslinking of TRAIL, TNF, and TWEAK ligands did not significantly increase the rate of apoptosis in CD4 + or CD8 + $T$ cells from SIVmac251-infected animals above the spontaneous rate (data not shown), suggesting that these ligands 
a
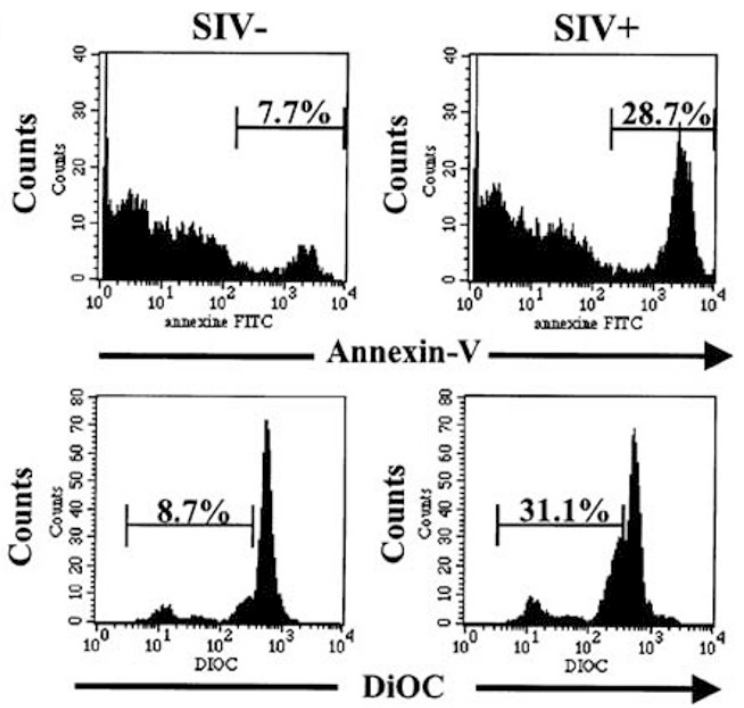

b

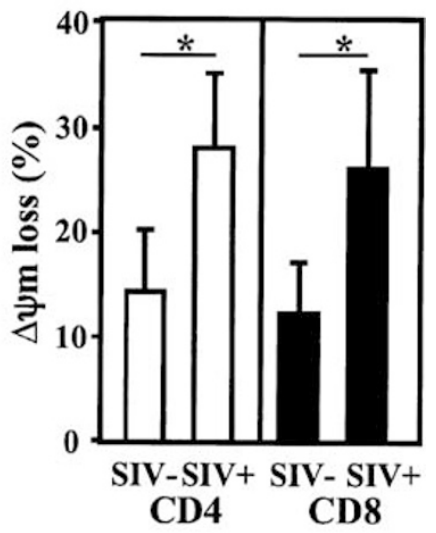

d
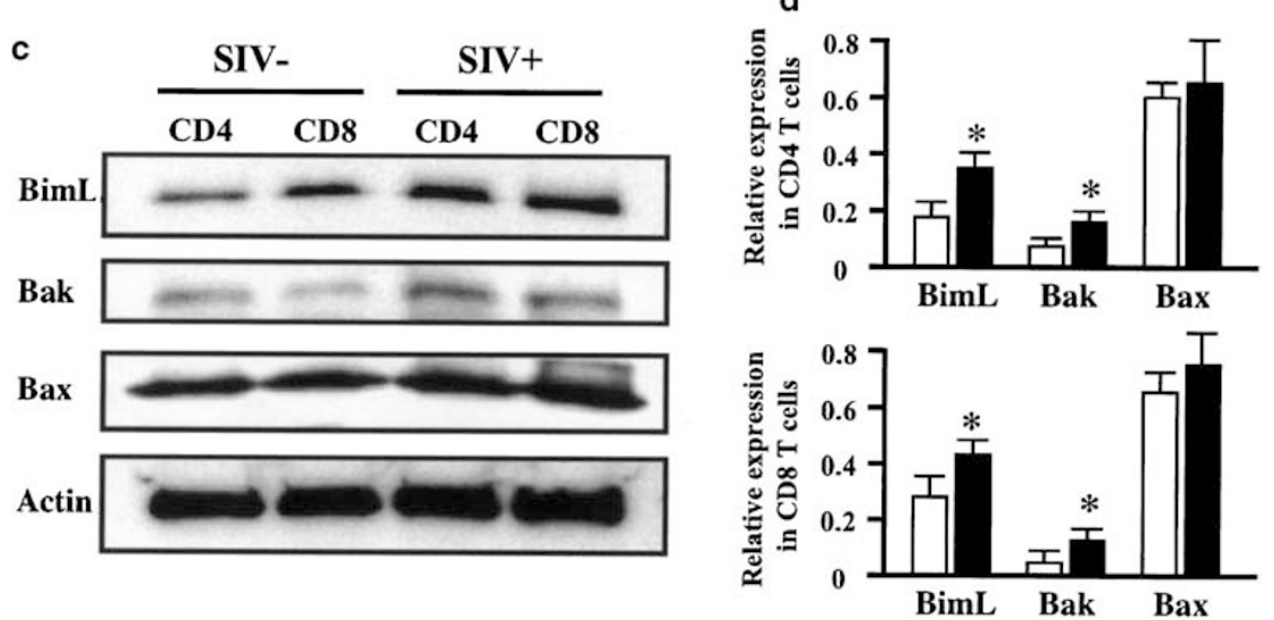

Figure 7 Mitochondrial membrane potential loss in SIV-infected macaques is associated with the upregulation of Bim and Bak. (a) Representative histograms showing measurement of phosphatidyl serine exposure (using FITC-labelled annexin-V) and of mitochondrial membrane potential (using DiOC 6 ) in PBMC of an uninfected (SIV-) macaque and an SIVmac251-infected macaque (SIV +). (b) Percentages of CD4 + and CD8 + T cells displaying $\Delta / \mathrm{m}$ loss. Results are the mean \pm S.D. of six individual SIV-infected (SIV + ) and four healthy macaques (SIV-). (c) Western blots of Bim, Bak, and Bax in CD4 + and CD8 + T cells from a healthy (SIV-) and a SIVmac251-infected macaque. Actin was used as a control for loading. (d) Relative levels of the proteins in three uninfected ( $\square$ ) and three SIVmac251-infected macaques ( $\mathbf{D})$. Relative levels were calculated by dividing the intensity of the signal for the proteins considered by the intensity of the actin signal. The intensity of the protein signal was assessed with $\mathrm{NIH}$ Image version 1.62. Statistical significance was assessed using Student's $t$-test $\left({ }^{*} P<0.05\right.$; ns: not significant)

play no more than a minimal role in the T-cell depletion observed during SIV infection.

Spontaneous apoptosis resulted in a loss of $\Delta \psi \mathrm{m}$, despite the presence of caspase inhibitor, suggesting that changes in mitochondrial permeability may be a central event in the regulation of T-cell death. The proapoptotic members of the Bcl-2 family have been shown to be involved in the mitochondrial membrane permeabilisation associated with $\Delta \psi \mathrm{m}$ loss. ${ }^{12,13}$ Bax overproduction in Jurkat cells has been reported to trigger the rapid targeting of Bax to the mitochondria, where it induces the loss of $\Delta \psi \mathrm{m}$ loss and cell death. ${ }^{42}$ It was recently reported that p53 phosphorylation may be involved in the upregulation of Bax in various in vitro models of HIV infection ${ }^{16,18}$ and that p53 phosphorylation in vivo is correlated with plasma viral load. ${ }^{16}$ Our data from
SIVmac251-infected macaques were not consistent with an association between T-cell death and an increase in Bax production. Our findings do not, however, exclude the possibility that SIV infection favours the translocation of Bax from the cytosol to the mitochondria, without a change in gene expression. Such a phenomenon has been reported in other cell types in response to growth factor deprivation. ${ }^{53}$ We did observe a clear increase in the levels of two other proapoptotic proteins, Bak and BimL. Bim, a 'BH3-only protein', binds to prosurvival members of the $\mathrm{Bcl}-2$ family and requires Bax or Bak for the induction of cell death ${ }^{54,55}$ by the caspaseindependent mitochondrial permeabilisation pathway. ${ }^{55}$ The overproduction of Bak also induces cell death through caspase-independent processes. ${ }^{43}$ Bim was recently reported to promote the death of autoreactive thymocytes and 
to be involved in cell death due to cytokine deprivation. ${ }^{56-59}$ Moreover, Bim is critical for the cell death of activated T and B cells. ${ }^{60}$ These proteins have not previously been implicated in cell death associated with HIV or SIV infection. The induction, by these proteins, of mitochondrial permeabilisation by caspase-independent mechanisms, and the observed increase in the levels of these proteins in SIV-infected monkeys suggest that the upregulation of Bak and Bim may be involved in the loss of $\Delta \psi \mathrm{m}$ loss and spontaneous T-cell death (Figure 8). The mechanisms underlying the upregulation of Bim and Bak upon SIV infection remain unclear.

Our results also provide insight into the mechanisms underlying the increase in susceptibility to apoptosis induced by CD95 ligation in T cells from SIVmac251-infected animals. Following the binding of CD95 to its ligand CD95L, several proteins from the death-inducing signalling complex (DISC) participate in activation of the initiator caspase-8. ${ }^{9,10}$ Once activated, caspase- 8 triggers the activation of downstream caspases, a process that can be modulated by zVAD-fmk. An alternative pathway was recently described. This pathway is independent of caspase-8, and involves the RIP kinase, which induces a necrotic death that is not prevented by zVAD-fmk. ${ }^{61}$
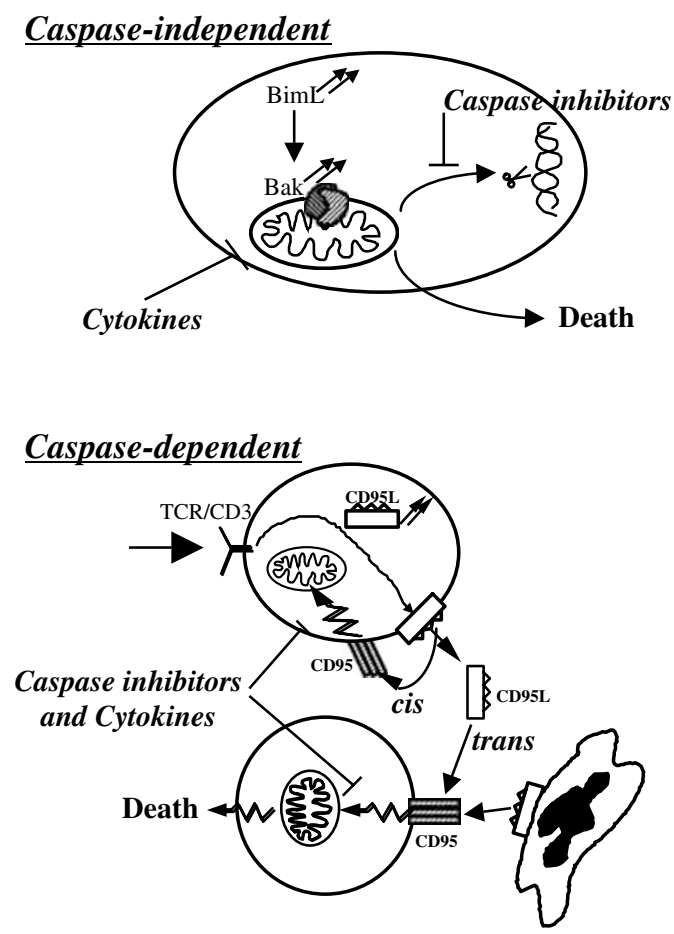

Figure 8 Two death pathways operating during SIV infection. Caspaseindependent cell death: Upregulation of the Bim and Bak proteins mediates mitochondrial membrane potential loss, leading to the release of apoptogenic factors from the mitochondria and further cell death. In this form of cell death, caspase inhibitor (zVAD-fmk) prevented the apoptotic phenotype (chromatin condensation and fragmentation) but did not prevent subsequent cell death. Cytokines, in contrast, prevented both the apoptotic phenotype and cell death, by preserving mitochondrial membrane potential. Caspase-dependent cell death: $T$ cells encountering either activated T cells that induce CD95L translocation from the cytosol to the membrane or neighbouring CD95L-expressing cells are more prone to cell death. In this form of cell death, death receptors activate caspases, leading to cytochrome $c$ release from the mitochondria and an amplification of caspase activation. Caspase inhibitor and, to a lesser extent, cytokines prevent mitochondrial damage and cell death
Here, we found that zVAD-fmk prevented CD95-mediated Tcell death, indicating that the process of cell death in $T$ cells from SIVmac251-infected animals was independent of RIP. FLIP-L and FLIP-S act as dominant-negative inhibitors of caspase-8, preventing the processing and release of active caspase- 8 from death receptors. ${ }^{62}$ However, we found that the increase in the rate of CD95-mediated T-cell death in rhesus macaques was not associated with a decrease in mRNA levels for FLIP-L and FLIP-S (Figure 3a). Moreover, although the proportion of CD4 + and CD8 $+\mathrm{T}$ cells from SIVmac251-infected macaques expressing CD95 tended to be higher than that of $T$ cells from uninfected animals, these differences were smaller than those observed in humans and were not statistically significant. This suggests that changes in CD95 expression are unlikely to account for the greater susceptibility of the cells to CD95-induced apoptosis.

Nef has been reported to sensitise cells to CD95-induced apoptosis. ${ }^{25,63}$ However, Nef is an intracellular protein and the proportion of infected CD4 + $\mathrm{T}$ cells from SIVmac251infected rhesus macaques did not exceed $2 \%$ of the total peripheral blood CD4 + T-cell population (data not shown). Thus, most of the cells undergoing apoptosis in vitro are not infected, suggesting that indirect mechanisms are involved. The interaction of the HIV envelope protein with the CD4 molecule may prime CD4 + and CD8 + T cells for CD95-mediated apoptosis. ${ }^{64-67}$ We recently demonstrated that the incubation of resting CD4 $+\mathrm{T}$ cells from healthy donors, even in the presence of an inhibitor of the viral replication, was sufficient to prime CD4 + T cells for apoptosis in response to CD95 ligation. ${ }^{68,69}$ This priming did not require further T-cell activation, suggesting that interactions between the virus and T cells are sufficient. In this study, we found that susceptibility to CD95-induced apoptosis and viral load were higher in SIVmac251-infected macaques that were progressors than in those that were slow progressors, and in animals infected with SIVmac251 than in animals infected with $\Delta$ nef. Consistent with a recent report indicating that the increase in CD95 sensitivity of CD8 + T cells from HIV-1-infected individuals is not correlated with plasma viral load, ${ }^{70}$ in individual SIV-infected macaques, changes in viral load and susceptibility to CD95-induced apoptosis were not strongly correlated. Other factors must therefore be involved.

One such factor may be the cytokine environment. We found that both IL-2 and IL-15 reduced the death rate of CD4 + and CD8 + T cells from SIVmac251-infected macaques following spontaneous induction ex vivo and induction by CD95 ligation. We have reported similar effects of IL-2 on the CD95L-induced killing of T cells from HIV-infected humans. ${ }^{39}$ IL-2 immunotherapy was recently shown to have beneficial effects on CD4 + T-cell counts during HAART in HIV-infected individuals. ${ }^{71}$ This raises the key question of whether these beneficial effects result from the prevention of T-cell apoptosis. This issue is currently under investigation in our laboratory, in a randomised, controlled cohort of French HIV-positive subjects.

Unlike IL-2 and IL-15, IL-7 did not prevent the spontaneous or CD95L-induced death of T cells. The receptors for all the three of these cytokines share a common $\gamma$-chain $(\gamma \mathrm{c})$ and use a common JAK3/STAT5 signalling pathway, but only the IL-2 and IL-15 receptors share the IL-2R $\beta$ subunit. ${ }^{72}$ Moreover, the 
activation of STAT5 by IL-2 has been reported to be involved in $\mathrm{T}$-cell proliferation and AICD, whereas the IL-2R $\beta$ chain has been reported to be involved in the activation of Akt and $\mathrm{Bcl}-2$ production. We found that IL-2 and IL-15 prevented cell death but IL-7 did not, suggesting that the IL-2R $\beta$ subunit is involved in this process. ${ }^{73} \mathrm{IL}-10$ also increased the survival rate of CD8 + T cells, but not CD4 + T cells, from SIVmac251infected macaques. These observations are reminiscent of previous studies showing that IL-10 can rescue human CD8 + T cells from apoptotic cell death. ${ }^{39,74,75}$ The signalling cascade activated by IL-10 differs from that used by IL-2 and IL-15. The binding of IL-10 to its receptor complex activates the JAK 1 and Tyk2 kinases and involves STAT3 and STAT1. ${ }^{76-78}$ Nevertheless, IL-2, IL-15, and IL-10 all prevented CD8 T-cell death and $\Delta \Psi \mathrm{m}$ loss, despite differences in the signal transduction pathway used. Preliminary observations in cells from SIVinfected macaques suggest that these cytokines increase Bcl2 production (data not shown), supporting the hypothesis that cytokines may enable antiapoptotic proteins to counteract the proapoptotic activity of Bim and Bak.

Finally, we found that the level of CD95L expression was much higher on $T$ cells from SIVmac251-infected macaques than on $T$ cells from uninfected animals. The mechanisms responsible for the induction of CD95L are unclear, but it has been suggested that the increase in CD95L levels observed in $T$ cells from HIV-infected humans result from immune activation and/or the interaction of $T$ cells with viral proteins, including gp120 and tat. ${ }^{79,80}$ Despite the observed increase in CD95L levels, this ligand did not appear to be involved in the spontaneous death of either CD4 + or CD8 + T cells. CD95L may remain sequestered in the cytosol, ${ }^{81}$ and engagement of the TCR/CD3 complex is required to trigger T-cell death. ${ }^{82} \mathrm{We}$ suggest that in the absence of T-cell activation, CD95L may not reach the cell membrane in sufficiently large amounts to exert its cytotoxic potential. As T cells from SIVmac251infected macaques are more prone to apoptosis after CD95 ligation, and may be primed to produce larger amounts of CD95L following activation, the interaction of these $T$ cells in vivo with neighbouring CD95L-producing cells (trans), and/or after TCR triggering (cis), may increase the rate of cell death (Figure 8). The resulting shortened half-life of activated cells in vivo may account for the CD95/CD95L pathway not appearing to contribute to spontaneous apoptosis ex vivo.

Our observations suggest that caspase-dependent and independent pathways may both play a role in the progressive decrease in the number of $\mathrm{T}$ cells during SIV infection. Moreover, our finding that cytokines prevented spontaneous T-cell death and caspase inhibitors prevented CD95mediated T-cell death suggest two complementary strategies that may restrict $\mathrm{T}$-cell depletion in vivo.

\section{Materials and methods}

\section{Human and primate blood samples}

Peripheral venous blood was obtained from HIV-1-seropositive adults and healthy HIV-seronegative controls followed by the Department of Infectious Diseases, Centre Hospitalier de Tourcoing, France. Blood samples were collected in heparinised tubes. HIV1-infected individuals had CD4 T-cell counts of $60-1200 / \mathrm{mm}^{3}$. Peripheral venous blood was also obtained from various primate species, and collected in heparinised tubes. Chimpanzees experimentally infected with the HIV-1-LAl strain and uninfected controls were housed at the Laboratory for Experimental Medicine and Surgery in Primates (LEMSIP), New York University Medical Center (Tuxedo, NY, USA). Rhesus macaques were housed at the Primate Centre, Pasteur Institute (Paris, France), and were experimentally infected either with the pathogenic SIVmac251 viral strain or with the nonpathogenic nef-deleted SIVmac251 clone.

\section{Antibodies and reagents}

Murine anti-human monoclonal antibodies recognising the following antigens were used: CD4, Leu 3a, and PercP-labelled Leu 3a (Becton Dickinson, Mountain View, CA, USA) or OKT4 (Ortho Diagnostic Systems, Roissy, France); CD8, Leu 2a, and PercP-labelled Leu 2a (Becton Dickinson); CD19, IOB4 (Beckman-Coulter, Marseille, France); CD56, IOT56 (Beckman-Coulter); CD69, FITC-labelled (Becton Dickinson); PElabelled DX2 (PharMingen, San Diego, CA, USA) HLA-DR, FITC-labelled (Becton Dickinson); control IgM isotype GC323 (Beckman Coulter). The other reagents used were: acridine orange stain (Beckman Coulter), DiOC6 (Molecular Probes), FITC-labelled Annexin-V (Beckman Coulter), and the irreversible caspase inhibitor ZVAD-fmk (Bâle Biochimie, Voisinsle-Bretonneaux, France). Recombinant human cytokines (IL-2, IL-7, IL-10, and IL-15) were purchased from R\&D Systems (Abingdon, UK). Soluble recombinant human CD95 ligand and a soluble CD95 decoy receptor (human CD95-Fc immunoglobulin fusion protein) were obtained from Alexis Corporation.

\section{Cell preparation and culture}

PBMC were isolated from heparinised venous blood by Ficoll-Hypaque density gradient centrifugation, and cultured in complete medium. ${ }^{43}$ In some experiments, PBMC were depleted of either CD4 + or CD8 + T cells by negative selection, using CD4 or CD8 mAb and magnetic beads coated with anti-mouse IgG (Dynal, Biosys, Compiègne, France), as previously described. ${ }^{6,83}$ Less than $5 \%$ contamination with $\mathrm{CD} 4+$ or CD8 + T cells was observed, as assessed by flow cytometry (FACScan, Becton Dickinson).

\section{Assessment of apoptosis}

Apoptotic cells were quantified by flow cytometry. We cultured $5 \times 10^{5}$ cells/well in complete medium for $24 \mathrm{~h}$ and labelled them with acridine orange, which stains nuclei $(0.1 \mu \mathrm{g} / \mathrm{ml})$; lymphocytes were gated based on forward- and side-light scattering. Apoptotic cells were identified on the basis of their characteristically lower fluorescence intensity and forwardlight scattering than living cells. ${ }^{83}$ The percentage of apoptotic cells was also quantified by flow cytometry, using FITC-conjugated annexin-V. A two-step procedure was used: cells were first stained with PercP-labelled anti-CD4 or anti-CD8 $\mathrm{mAbs}\left(30 \mathrm{~min}\right.$ at $\left.4^{\circ} \mathrm{C}\right)$, and then, after washing in PBS, they were incubated in binding buffer with FITC-Annexin-V (Ax) according to the manufacturer's instructions. ${ }^{24}$ Apoptosis was calculated as follows: $\left(\mathrm{CD}^{+}{ }^{+} \mathrm{Ax}^{+}\right) /\left(\mathrm{CD} 4{ }^{+} \mathrm{Ax}^{+}+\mathrm{CD}^{+}{ }^{+} \mathrm{Ax}^{-}\right) \times 100$. Mitochondrial membrane potential was assessed using $\mathrm{DiOC}_{6}$, as previously described. $^{17}$

\section{Specific cytotoxicity mediated by CD95L}

Functional CD95L levels were determined by coculturing PBMC, CD4 + T cells, and CD8 + T cells from macaques with effector cells (Jurkat cells) at 
various $E / T$ ratios for $16 \mathrm{~h}$ in round-bottomed plates. Cytotoxicity was assessed by flow cytometry, using a PC5-labelled anti-CD4 mAb (Beckman Coulter) that recognised only the human CD4 molecule, and FITC-labelled annexin-V. We analysed 4000 target cells. As a control, Jurkat cells were incubated in the absence or presence of $100 \mathrm{ng} / \mathrm{ml} \mathrm{rh}$ CD95L. The percentage of dying cells was calculated as follows: ((experimental cell death-spontaneous cell death)/(CD95L mediated cell death-spontaneous cell death) $\times 100$. In some experiments, cells were incubated in the presence of $20 \mu \mathrm{g} / \mathrm{ml}$ of a CD95-Fc fusion protein that blocks the interaction between CD95 and its ligand.

\section{Determination of caspase activity}

The cell-permeable fluorogenic caspase substrate Phiphilux-G2D2 (Oncolmmunin, Gaithersburg, MD, USA) was used to monitor caspase activity. Cells were cultured for $24 \mathrm{~h}$, collected by centrifugation, and resuspended in $50 \mu$ l of Phiphilux-G2D2 substrate solution supplemented with $5 \%$ foetal calf serum. Cells were incubated for $45 \mathrm{~min}$ at $37^{\circ} \mathrm{C}$ in an atmosphere containing $5 \% \mathrm{CO}_{2}$, in an incubator. The cells were pelleted and resuspended in $500 \mu \mathrm{l}$ of Phiphilux dilution buffer, and fluorescence was determined with a FACScan flow cytometer (Becton Dickinson).

\section{Western blotting}

For total extracts, cells were incubated in SDS lysis buffer, boiled for $10 \mathrm{~min}$ and centrifuged $400 \times g$ for $15 \mathrm{~min}$ at room temperature. Protein concentration was determined with the DC Protein Assay (BioRad Laboratories, Hercules, CA, USA). Equal amounts of protein were boiled for 5 min in $2 \times$ Laemmli sample buffer with $2-\beta$ mercaptoethanol and run on a $4 / 20 \%$ polyacrylamide gel (BioRad Laboratories). Proteins were then transferred to a PVDF membrane (BioRad Laboratories), which was probed with specific antibodies. Antibody binding was detected by incubation with horseradish peroxidase-conjugated secondary antibodies (Amersham, Orsay, France), and enhanced chemiluminescence (Amersham). The antibodies used were a mouse anti-CD95L antibody (clone 13, Transduction Laboratories, San Diego, CA, USA), ${ }^{84}$ a rabbit polyclonal anti-Bax antibody (N-20 and P19, Santa Cruz Biotechnology, Santa Cruz, CA, USA), a rabbit polyclonal anti-Bak antibody (Calbiochem, Meudon, France), a rabbit polyclonal anti-Bim antibody (Stressgen, Victoria, Canada), and a mouse anti-actin mAb (clone AC40, Sigma).

\section{Quantification of mRNA}

Total RNA was purified from $5 \times 10^{6}$ PBMC using RNAzol (Bioprobe Systems, Montreuil-sous-Bois, France), and quantified by measurement of absorbance at $260 \mathrm{~nm}$. First-strand cDNA was synthesised by incubating $3 \mu \mathrm{g}$ of total RNA with Moloney murine leukaemia virus reverse transcriptase (Life Technologies, Gaithersburg, MD, USA) and $1.25 \mu \mathrm{M}$ random hexanucleotide primers (Pharmacia Biotech, Uppsala, Sweden) for $1 \mathrm{~h}$ at $42^{\circ} \mathrm{C}$ under the conditions recommended by the manufacturer. The resulting samples were stored at $-80^{\circ} \mathrm{C}$.

To ensure that samples could be compared, we then determined the amount of cDNA corresponding to the abundant ribosomal protein $\mathrm{S} 14$ in each cDNA preparation by competitive PCR, performed as previously described. ${ }^{85}$ An internal standard 4 bp shorter than the target sequence was used.

Macaque cDNAs (CD95: genebank number AF530075; forward primer: 5'-CAGAACTTGGAAGGCCTGCATCAC; reverse primer: 5'-GCACGCAGTCTGGTTCATCCTCA; probe: 5'-GGAAAGCTAGGGACTGCAC. CD95L: GenBank accession number AF530076; forward primer: 5'-
ACCAGCCAGAAGCATACAGCATCA; reverse primer: 5'-CCATAGGTGTCTTCCCATTCCAGAG; probe: 5'-GGAGAAGCAAATAGGTCACC) were quantified by PCR as previously described (R1). Briefly, reaction mixtures (final volume $100 \mu \mathrm{l}$ ) contained $20 \mathrm{mM}$ Tris-HCl (pH 8.4), $50 \mathrm{mM}$ $\mathrm{KCl}, 1.5 \mathrm{mM} \mathrm{MgCl}_{2}, 200 \mathrm{mM}$ each dNTP, $10 \mathrm{pmol}$ of oligonucleotide primers, $2.5 \mathrm{U}$ Taq polymerase (Life Technologies), and cDNA. All samples were amplified during the same PCR, and an equivalent amount of cDNA, quantified as described above, was used in each case. Cycling parameters were as follows: denaturation, $95^{\circ} \mathrm{C}$ for $1 \mathrm{~min}$; annealing, $60^{\circ} \mathrm{C}$ (CD95, CD95-L); extension, $72^{\circ} \mathrm{C}$ for $1 \mathrm{~min}$. In preliminary experiments, the optimal number of cycles was determined for each cDNA such that samples would be obtained during the exponential phase of the PCR reaction. After the appropriate number of cycles (CD95, 30 cycles; CD95L, 34 cycles), aliquots from each reaction mixture were removed, DNA was denatured, and samples were applied to Hybond-N nylon membranes (Amersham) in a dot-blot format. The membranes were hybridised with a probe that recognised a sequence within the amplification product, which had been labelled at the $5^{\prime}$-end using T4 polynucleotide kinase (Life Technologies) and $\left(\gamma^{32}\right.$ P)ATP. The membrane was washed and bound radioactivity quantified by electronic autoradiography (Instant Imager, Packard, Meriden, CT, USA). Results are expressed as CPM after subtraction of background ( $<50 \mathrm{CPM}$ in all experiments). Results are the means of duplicate determinations for each sample. In all cases, the addition of half the normal amount of cDNA to the initial reaction resulted in the expected $50 \%$ reduction in signal (data not shown).

\section{Quantification of plasma viral load}

A sensitive quantitative competitive (QC) RT-PCR assay was used for to monitor SIV RNA levels in plasma samples. Plasma samples that had only been thawed once were centrifuged at $10000 \times g$ for $2 \mathrm{~h}$ to concentrate SIV virions. RNA was extracted with phenol : chloroform : isoamyl alcohol and precipitated by incubation overnight with ethanol at $-20^{\circ} \mathrm{C}$. For the RT reaction, $5 \mu \mathrm{l}$ of viral RNA was diluted 1:4 in DEPC-treated water, and $15 \mu$ of RT mix $-1 \times$ PCR Buffer II (Perkin-Elmer), $5 \mathrm{mM} \mathrm{MgCl}_{2}, 1 \mathrm{mM}$ each dNTP, $2.5 \mathrm{mM}$ oligo $\mathrm{d}(\mathrm{T})$ primer, RNase inhibitor (RNAguard, Pharmacia) and $50 \mathrm{U}$ of reverse transcriptase (MMLV Superscript, Gibco) - was added. The RT reaction was performed at $42^{\circ} \mathrm{C}$ for $30 \mathrm{~min}$ and the enzyme was then inactivated by heating at $95^{\circ} \mathrm{C}$ for $5 \mathrm{~min}$. A known number of copies of competitor DNA was added to the cDNA. The competitor DNA consisted of a plasmid containing a nef gene with a $175 \mathrm{bp}$ deletion. The following primers were used for nested amplification of nef sequences in the sample and competitor: Preco (5'-CAG AGG CTC TCT GCG ACC CTA C-3') and K3 (5'-GAC TGA ATA CAG AGC GAA ATG C-3') for the first amplification, K1 (5'-TGG AAG ATG GAT CCT CGC AAT CC- $3^{\prime}$ ) and A2 (5'-GGA CTA ATT TCC ATA GCC AGC CA-3') for the second amplification. Cycling parameters were as follows: $95^{\circ} \mathrm{C}$ for $1 \mathrm{~min}$ followed by 35 cycles of $95^{\circ} \mathrm{C}$ for $30 \mathrm{~s}, 60^{\circ} \mathrm{C}$ for $45 \mathrm{~s}$, and $72^{\circ} \mathrm{C}$ for $1 \mathrm{~min}$, followed by extension at $72^{\circ} \mathrm{C}$ for $7 \mathrm{~min}$. For the second PCR, $5 \mu \mathrm{l}$ of the first amplification product was amplified for 25 cycles as above, except that an annealing temperature of $55^{\circ} \mathrm{C}$ was used. Amplified products were separated on $2.5 \%$ agarose gels and stained with ethidium bromide. RNA copy number was determined from the competitor-template equivalence point by direct visual examination of the photographed gel.

\section{Statistical analysis}

Statistical significance was assessed by Student's t-test or Student's paired $t$-test, as appropriate. A value of $P<0.05$ was considered significant. 


\section{Acknowledgements}

This work was supported by Institut National de la Santé et de la Recherche Médicale (INSERM), Paris 7 University and grants from Agence National de Recherches sur le Sida (ANRS), Ensemble Contre le Sida (ECS), Fondation de la Recherche Médicale (FRM) and a Paris 7 University valorisation grant (JCA), and doctoral fellowships from ANRS (JDL), ECS (FP), and from DGA and FRM (DA). We thank Elisabeth Muchmore at the Laboratory for Experimental Medicine and Surgery in Primates (New York University Medical Center, Tuxedo, NY 10987, USA) and Marc Girard at the Institut Pasteur (75724 Paris, France) for kindly providing blood samples from chimpanzees, and Yves Mouton at Hôpital Dron (59208 Tourcoing, France) for clinical work.

\section{References}

1. Ho DD, Neumann AU, Perelson AS, Chen W, Leonard JM and Markowitz M (1995) Rapid turnover of plasma virions and CD4 lymphocytes in HIV-1 infection (see comments). Nature 373: 123-126

2. Clerici M, Stocks NI, Zajac RA, Boswell RN, Lucey DR, Via CS and Shearer GM (1989) Detection of three distinct patterns of $T$ helper cell dysfunction in asymptomatic, human immunodeficiency virus-seropositive patients. Independence of CD4+ cell numbers and clinical staging. Journal Title:J. Clin. Invest. 84: 1892-1899

3. Ameisen JC, Estaquier J and Idziorek T (1994) From AIDS to parasite infection: pathogen-mediated subversion of programmed cell death as a mechanism for immune dysregulation. Immunol. Rev. 142: 9-51

4. Badley AD, Pilon AA, Landay A and Lynch DH (2000) Mechanisms of HIVassociated lymphocyte apoptosis. Blood 96: 2951-2964

5. de Oliveira Pinto LM, Garcia S, Lecoeur H, Rapp C and Gougeon ML (2002) Increased sensitivity of $\mathrm{T}$ lymphocytes to tumor necrosis factor receptor 1 (TNFR1)- and TNFR2-mediated apoptosis in HIV infection: relation to expression of Bcl-2 and active caspase-8 and caspase-3. Blood 99: 1666-1675

6. Muro-Cacho CA, Pantaleo G and Fauci AS (1995) Analysis of apoptosis in lymph nodes of HIV-infected persons. Intensity of apoptosis correlates with the general state of activation of the lymphoid tissue and not with stage of disease or viral burden. J. Immunol. 154: 5555-5566

7. Gougeon ML, Lecoeur H, Dulioust A, Enouf MG, Crouvoiser M, Goujard C, Debord T and Montagnier L (1996) Programmed cell death in peripheral lymphocytes from HIV-infected persons: increased susceptibility to apoptosis of CD4 and CD8 T cells correlates with lymphocyte activation and with disease progression. J. Immunol. 156: 3509-3520

8. Meyaard L, Otto SA, Keet IP, Roos MT and Miedema F (1994) Programmed death of $T$ cells in human immunodeficiency virus infection. No correlation with progression to disease. J. Clin. Invest. 93: 982-988

9. Hengartner MO (2000) The biochemistry of apoptosis. Nature 407: 770-776

10. Kaufmann SH and Hengartner MO (2001) Programmed cell death: alive and well in the new millennium. Trends Cell. Biol. 11: 526-534

11. Leist $M$ and Jaattela $M(2001)$ Four deaths and a funeral: from caspases to alternative mechanisms. Nat. Rev. Mol. Cell. Biol. 2: 589-598

12. Desagher S and Martinou JC (2000) Mitochondria as the central control point of apoptosis. Trends Cell. Biol. 10: 369-377

13. Martinou JC and Green DR (2001) Breaking the mitochondrial barrier. Nat. Rev. Mol. Cell. Biol. 2: 63-67

14. Wei MC, Zong WX, Cheng EH, Lindsten T, Panoutsakopoulou V, Ross AJ, Roth KA, MacGregor GR, Thompson CB and Korsmeyer SJ (2001) Proapoptotic $B A X$ and BAK: a requisite gateway to mitochondrial dysfunction and death. Science 292: 727-730

15. Ferri KF, Jacotot E, Blanco J, Este JA, Zamzami N, Susin SA, Xie Z, Brothers G, Reed JC, Penninger JM and Kroemer G (2000) Apoptosis control in syncytia induced by the HIV type 1-envelope glycoprotein complex: role of mitochondria and caspases. J. Exp. Med. 192: 1081-1092

16. Castedo M, Ferri KF, Blanco J, Roumier T, Larochette N, Barretina J, Amendola A, Nardacci R, Metivier D, Este JA, Piacentini M and Kroemer G (2001) Human immunodeficiency virus 1 envelope glycoprotein complexinduced apoptosis involves mammalian target of rapamycin/FKBP12- rapamycin-associated protein-mediated p53 phosphorylation. J. Exp. Med. 194: $1097-1110$

17. Petit F, Arnoult D, Lelievre JD, Moutouh-de Parseval L, Hance AJ, Schneider P, Corbeil J, Ameisen JC and Estaquier J (2002) Productive HIV-1 infection of primary $\mathrm{CD} 4+\mathrm{T}$ cells induces mitochondrial membrane permeabilization leading to a caspase-independent cell death. J. Biol. Chem. 277: 1477-1487

18. Genini D, Sheeter D, Rought S, Zaunders JJ, Susin SA, Kroemer G, Richman DD, Carson DA, Corbeil J and Leoni LM (2001) HIV induces lymphocyte apoptosis by a $p 53$-initiated, mitochondrial-mediated mechanism. FASEB J. 15: 5-6

19. Corbeil J, Sheeter D, Genini D, Rought S, Leoni L, Du P, Ferguson M, Masys DR, Welsh JB, Fink JL, Sasik R, Huang D, Drenkow J, Richman DD and Gingeras T (2001) Temporal gene regulation during HIV-1 infection of human CD4+ T cells. Genome Res. 11: 1198-1204

20. Regamey N, Harr T, Battegay M and Erb P (1999) Downregulation of Bcl-2, but not of Bax or Bcl-x, is associated with T lymphocyte apoptosis in HIV infection and restored by antiretroviral therapy or by interleukin 2. AIDS Res. Hum. Retroviruses 15: 803-810

21. Scheuring UJ, Sabzevari H, Corbeil J and Theofilopoulos AN (1999) Differential expression profiles of apoptosis-affecting genes in HIV-infected cell lines and patient T cells. AIDS 13: 167-175

22. Rosenzweig M, Connole M, Forand-Barabasz A, Tremblay MP, Johnson RP and Lackner AA (2000) Mechanisms associated with thymocyte apoptosis induced by simian immunodeficiency virus. J. Immunol. 165: 3461-3468

23. Iida $T$, Igarashi $T$, Ichimura $H$, Kuwata $T$, Shimada T, Nagamachi D, Yonehara S, Imanishi J and Hayami M (1998) Fas antigen expression and apoptosis of lymphocytes in macaques infected with simian immunodeficiency virus strain mac. Arch. Virol. 143: 717-729

24. Estaquier J, Monceaux V, Cumont MC, Aubertin AM, Hurtrel B and Ameisen JC (2000) Early changes in peripheral blood T cells during primary infection of rhesus macaques with a pathogenic SIV. J. Med. Primatol. 29: 127-135

25. Xu XN, Screaton GR, Gotch FM, Dong T, Tan R, Almond N, Walker B, Stebbings R, Kent K, Nagata S, Stott JE and McMichael AJ (1997) Evasion of cytotoxic T lymphocyte (CTL) responses by Nef-dependent induction of Fas ligand (CD95L) expression on simian immunodeficiency virus-infected cells. J. Exp. Med. 186: 7-16

26. Murayama $\mathrm{Y}$, Terao K and Inoue-Murayama M (2000) Molecular cloning and characterization of cynomolgus monkey Fas. Hum. Immunol. 61: 474-485

27. Kestler III HW, Ringler DJ, Mori K, Panicali DL, Sehgal PK, Daniel MD and Desrosiers RC (1991) Importance of the nef gene for maintenance of high virus loads and for development of AIDS. Cell 65: 651-662

28. Klas C, Debatin KM, Jonker RR and Krammer PH (1993) Activation interferes with the APO-1 pathway in mature human T cells. Int. Immunol. 5: 625-630

29. McLeod JD, Walker LS, Patel YI, Boulougouris G and Sansom DM (1998) Activation of human $T$ cells with superantigen (staphylococcal enterotoxin $B$ ) and CD28 confers resistance to apoptosis via CD95. J. Immunol. 160: 20722079

30. Holmstrom TH, Chow SC, Elo I, Coffey ET, Orrenius S, Sistonen L and Eriksson JE (1998) Suppression of Fas/APO-1-mediated apoptosis by mitogen-activated kinase signaling. J. Immunol. 160: 2626-2636

31. Yeh JH, Hsu SC, Han SH and Lai MZ (1998) Mitogen-activated protein kinase kinase antagonized fas-associated death domain protein-mediated apoptosis by induced FLICE-inhibitory protein expression. J. Exp. Med. 188: 1795-1802

32. Badley AD, Dockrell DH, Algeciras A, Ziesmer S, Landay A, Lederman MM, Connick E, Kessler H, Kuritzkes D, Lynch DH, Roche P, Yagita H and Paya CV (1998) In vivo analysis of Fas/FasL interactions in HIV-infected patients. J. Clin. Invest. 102: 79-87

33. Mitra D, Steiner M, Lynch DH, Staiano-Coico L and Laurence J (1996) HIV-1 upregulates Fas ligand expression in CD4+ $\mathrm{T}$ cells in vitro and in vivo: association with Fas-mediated apoptosis and modulation by aurintricarboxylic acid. Immunology 87: 581-585

34. Sloand EM, Young NS, Kumar P, Weichold FF, Sato T and Maciejewski JP (1997) Role of Fas ligand and receptor in the mechanism of T-cell depletion in acquired immunodeficiency syndrome: effect on CD4+ lymphocyte depletion and human immunodeficiency virus replication. Blood 89: 1357-1363

35. Xu XN, Laffert B, Screaton GR, Kraft M, Wolf D, Kolanus W, Mongkolsapay J, McMichael AJ and Baur AS (1999) Induction of Fas ligand expression by HIV involves the interaction of Nef with the T cell receptor zeta chain. J. Exp. Med. 189: $1489-1496$ 
36. Naidu YM, Kestler III HW, Li Y, Butler CV, Silva DP, Schmidt DK, Troup CD, Sehgal PK, Sonigo P, Daniel MD and Desrosiers RC (1988) Characterization of infectious molecular clones of simian immunodeficiency virus (SIVmac) and human immunodeficiency virus type 2: persistent infection of rhesus monkeys with molecularly cloned SIVmac. J. Virol. 62: 4691-4696

37. Baumler CB, Bohler T, Herr I, Benner A, Krammer PH and Debatin KM (1996) Activation of the CD95 (APO-1/Fas) system in $T$ cells from human immunodeficiency virus type-1-infected children. Blood 88: 1741-1746

38. Estaquier J, Idziorek T, Zou W, Emilie D, Farber CM, Bourez JM and Ameisen JC (1995) T helper type 1/T helper type 2 cytokines and T cell death: preventive effect of interleukin 12 on activation-induced and CD95 (FAS/APO-1)-mediated apoptosis of CD4+ $\mathrm{T}$ cells from human immunodeficiency virus-infected persons. J. Exp. Med. 182: 1759-1767

39. Estaquier J, Tanaka M, Suda T, Nagata S, Golstein P and Ameisen JC (1996) Fas-mediated apoptosis of $\mathrm{CD} 4+$ and $\mathrm{CD} 8+\mathrm{T}$ cells from human immunodeficiency virus-infected persons: differential in vitro preventive effect of cytokines and protease antagonists. Blood 87: 4959-4966

40. Katsikis PD, Wunderlich ES, Smith CA and Herzenberg LA (1995) Fas antigen stimulation induces marked apoptosis of $\mathrm{T}$ lymphocytes in human immunodeficiency virus-infected individuals. J. Exp. Med. 181: 2029-2036

41. McCloskey TW, Bakshi S, Than S, Arman P and Pahwa S (1998) Immunophenotypic analysis of peripheral blood mononuclear cells undergoing in vitro apoptosis after isolation from human immunodeficiency virus-infected children. Blood 92: 4230-4237

42. Xiang J, Chao DT and Korsmeyer SJ (1996) BAX-induced cell death may not require interleukin 1 beta-converting enzyme-like proteases. Proc. Natl. Acad. Sci. USA 93: 14559-14563

43. McCarthy NJ, Whyte MK, Gilbert CS and Evan Gl (1997) Inhibition of Ced-3/ ICE-related proteases does not prevent cell death induced by oncogenes, DNA damage, or the Bcl-2 homologue Bak. J. Cell. Biol. 136: 215-227

44. Vercammen D, Brouckaert G, Denecker G, Van de Craen M, Declercq W, Fiers $W$ and Vandenabeele $P(1998)$ Dual signaling of the Fas receptor: initiation of both apoptotic and necrotic cell death pathways. J. Exp. Med. 188: 919-930

45. Kawahara A, Ohsawa Y, Matsumura H, Uchiyama Y and Nagata S (1998) Caspase-independent cell killing by Fas-associated protein with death domain. J. Cell. Biol. 143: 1353-1360

46. Gandhi RT, Chen BK, Straus SE, Dale JK, Lenardo MJ and Baltimore D (1998) HIV-1 directly kills CD4+ T cells by a Fas-independent mechanism. J. Exp. Med. 187: 1113-1122

47. Miura $\mathrm{Y}$, Misawa $\mathrm{N}$, Maeda $\mathrm{N}$, Inagaki $\mathrm{Y}$, Tanaka $\mathrm{Y}$, Ito $\mathrm{M}$, Kayagaki $\mathrm{N}$ Yamamoto N, Yagita H, Mizusawa H and Koyanagi $Y$ (2001) Critical contribution of tumor necrosis factor-related apoptosis-inducing ligand (TRAIL) to apoptosis of human CD4+ T cells in HIV-1-infected hu-PBL-NOD-SCID mice. J. Exp. Med. 193: 651-660

48. Katsikis PD, Garcia-Ojeda ME, Torres-Roca JF, Tijoe IM, Smith CA and Herzenberg LA (1997) Interleukin-1 beta converting enzyme-like protease involvement in Fas-induced and activation-induced peripheral blood $\mathrm{T}$ cell apoptosis in HIV infection. TNF-related apoptosis-inducing ligand can mediate activation-induced T cell death in HIV infection. J. Exp. Med. 186: 1365-1372

49. Jeremias I, Herr I, Boehler T and Debatin KM (1998) TRAIL/Apo-2-ligandinduced apoptosis in human T cells. Eur. J. Immunol. 28: 143-152

50. Herbein G, Mahlknecht U, Batliwalla F, Gregersen P, Pappas T, Butler J O'Brien WA and Verdin E (1998) Apoptosis of CD8+ T cells is mediated by macrophages through interaction of HIV gp120 with chemokine receptor CXCR4. Nature 395: 189-194

51. Katsikis PD, Garcia-Ojeda ME, Wunderlich ES, Smith CA, Yagita H, Okumura K, Kayagaki N, Alderson M and Herzenberg LA (1996) Activation-induced peripheral blood T cell apoptosis is Fas independent in HIV-infected individuals. Int. Immunol. 8: 1311-1317

52. Lecossier D, Bouchonnet F, Schneider P, Clavel F and Hance AJ (2001) Discordant increases in CD4+ T cells in human immunodeficiency virusinfected patients experiencing virologic treatment failure: role of changes in thymic output and T cell death. J. Infect. Dis. 183: 1009-1016

53. Gross A, Jockel J, Wei MC and Korsmeyer SJ (1998) Enforced dimerization of BAX results in its translocation, mitochondrial dysfunction and apoptosis. EMBO J. 17: 3878-3885

54. Zong WX, Lindsten T, Ross AJ, MacGregor GR and Thompson CB (2001) $\mathrm{BH} 3-$ only proteins that bind pro-survival $\mathrm{Bcl}-2$ family members fail to induce apoptosis in the absence of Bax and Bak. Genes Dev. 15: 1481-1486
55. Cheng EH, Wei MC, Weiler S, Flavell RA, Mak TW, Lindsten T and Korsmeyer SJ (2001) BCL-2, BCL-X(L) sequester BH3 domain-only molecules preventing BAX- and BAK-mediated mitochondrial apoptosis. Mol. Cell 8: 705-711

56. Bouillet $P$, Metcalf D, Huang DC, Tarlinton DM, Kay TW, Kontgen F, Adams JM and Strasser A (1999) Proapoptotic Bcl-2 relative Bim required for certain apoptotic responses, leukocyte homeostasis, and to preclude autoimmunity. Science 286: 1735-1738

57. Bouillet P, Purton JF, Godfrey DI, Zhang LC, Coultas L, Puthalakath H, Pellegrini M, Cory S, Adams JM and Strasser A (2002) BH3-only Bcl-2 family member Bim is required for apoptosis of autoreactive thymocytes. Nature 415 : 922-926

58. Dijkers PF, Medema RH, Lammers JW, Koenderman L and Coffer PJ (2000) Expression of the pro-apoptotic Bcl-2 family member Bim is regulated by the forkhead transcription factor FKHR-L1. Curr. Biol. 10: 1201-1204

59. Shinjyo T, Kuribara R, Inukai T, Hosoi H, Kinoshita T, Miyajima A, Houghton PJ, Look AT, Ozawa K and Inaba T (2001) Downregulation of Bim, a proapoptotic relative of $\mathrm{Bcl}-2$, is a pivotal step in cytokine-initiated survival signaling in murine hematopoietic progenitors. Mol. Cell. Biol. 21: 854-864

60. Hildeman DA, Zhu Y, Mitchell TC, Kappler J and Marrack P (2002) Molecular mechanisms of activated T cell death in vivo. Curr. Opin. Immunol. 14: 354-359

61. Holler N, Zaru R, Micheau O, Thome M, Attinger A, Valitutti S, Bodmer JL, Schneider P, Seed B and Tschopp J (2000) Fas triggers an alternative, caspase-8-independent cell death pathway using the kinase RIP as effector molecule. Nat. Immunol. 1: 489-495

62. Thome M and Tschopp J (2001) Regulation of lymphocyte proliferation and death by FLIP. Nat. Rev. Immunol. 1: 50-58

63. Zauli G, Gibellini D, Secchiero P, Dutartre H, Olive D, Capitani S and Collette $Y$ (1999) Human immunodeficiency virus type 1 Nef protein sensitizes CD4(+) T lymphoid cells to apoptosis via functional upregulation of the CD95/CD95 ligand pathway. Blood 93: 1000-1010

64. Wang ZQ, Dudhane A, Orlikowsky T, Clarke K, Li X, Darzynkiewicz Z and Hoffmann MK (1994) CD4 engagement induces Fas antigen-dependent apoptosis of T cells in vivo. Eur. J. Immunol. 24: 1549-1552

65. Desbarats J, Freed JH, Campbell PA and Newell MK (1996) Fas (CD95) expression and death-mediating function are induced by CD4 cross-linking on CD4+ T cells. Proc. Natl. Acad. Sci. USA 93: 11014-11018

66. Vlahakis SR, Algeciras-Schimnich A, Bou G, Heppelmann CJ, Villasis-Keever A, Collman RC and Paya CV (2001) Chemokine-receptor activation by Env determines the mechanism of death in HIV-infected and uninfected T lymphocytes. J. Clin. Invest. 107: 207-215

67. Algeciras A, Dockrell DH, Lynch DH and Paya CV (1998) CD4 regulates susceptibility to Fas ligand- and tumor necrosis factor-mediated apoptosis. J. Exp. Med. 187: 711-720

68. Petit F, Corbeil J, Lelievre JD, Parseval LM, Pinon G, Green DR, Ameisen JC and Estaquier J (2001) Role of CD95-activated caspase-1 processing of IL1beta in TCR-mediated proliferation of HIV-infected CD4(+) T cells. Eur. J. Immunol. 31: 3513-3524

69. Estaquier J, Lelievre JD, Petit F, Brunner T, Moutouh-De Parseval L, Richman DD, Ameisen JC and Corbeil J (2002) Effects of antiretroviral drugs on human immunodeficiency virus type 1-induced CD4(+) T-cell death. J. Virol. 76: 59665973

70. Mueller YM, De Rosa SC, Hutton JA, Witek J, Roederer M, Altman JD and Katsikis PD (2001) Increased CD95/Fas-induced apoptosis of HIV-specific CD8(+) T cells. Immunity 15: 871-882

71. Kovacs JA, Baseler M, Dewar RJ, Vogel S, Davey Jr RT, Falloon J, Polis MA, Walker RE, Stevens R and Salzman NP et al. (1995) Increases in CD4 T lymphocytes with intermittent courses of interleukin-2 in patients with human immunodeficiency virus infection. A preliminary study. N. Engl. J. Med. 332: $567-575$

72. Waldmann T, Tagaya $Y$ and Bamford $R$ (1998) Interleukin-2, interleukin-15, and their receptors. Int. Rev. Immunol. 16: 205-226

73. Van Parijs L, Refaeli Y, Lord JD, Nelson BH, Abbas AK and Baltimore D (1999) Uncoupling IL-2 signals that regulate $T$ cell proliferation, survival, and Fasmediated activation-induced cell death. Immunity 11: 281-288

74. Cohen SB, Crawley JB, Kahan MC, Feldmann M and Foxwell BM (1997) Interleukin-10 rescues $T$ cells from apoptotic cell death: association with an upregulation of $\mathrm{BCl}-2$. Immunology 92: 1-5

75. Taga K, Cherney B and Tosato G (1993) IL-10 inhibits apoptotic cell death in human T cells starved of IL-2. Int. Immunol. 5: 1599-1608 
76. Tan JC, Indelicato SR, Narula SK, Zavodny PJ and Chou CC (1993) Characterization of interleukin-10 receptors on human and mouse cells. J. Biol. Chem. 268: 21053-21059

77. Kotenko SV, Krause CD, Izotova LS, Pollack BP, Wu W and Pestka S (1997) Identification and functional characterization of a second chain of the interleukin-10 receptor complex. EMBO J. 16: 5894-5903

78. Ho AS, Liu Y, Khan TA, Hsu DH, Bazan JF and Moore KW (1993) A receptor for interleukin 10 is related to interferon receptors. Proc. Natl. Acad. Sci. USA 90: $11267-11271$

79. Westendorp MO, Frank R, Ochsenbauer C, Stricker K, Dhein J, Walczak H, Debatin KM and Krammer PH (1995) Sensitization of T cells to CD95-mediated apoptosis by HIV-1 Tat and gp120. Nature 375: 497-500

80. Oyaizu N, Adachi Y, Hashimoto F, McCloskey TW, Hosaka N, Kayagaki N, Yagita $\mathrm{H}$ and Pahwa S (1997) Monocytes express Fas ligand upon CD4 crosslinking and induce $\mathrm{CD} 4+\mathrm{T}$ cells apoptosis: a possible mechanism of bystander cell death in HIV infection. J. Immunol. 158: 2456-2463
81. Bossi G and Griffiths GM (1999) Degranulation plays an essential part in regulating cell surface expression of Fas ligand in T cells and natural killer cells. Nat. Med. 5: 90-96

82. Vignaux F, Vivier E, Malissen B, Depraetere V, Nagata S and Golstein P (1995) TCR/CD3 coupling to Fas-based cytotoxicity. J. Exp. Med. 181: 781-786

83. Estaquier J, Idziorek T, de Bels F, Barre-Sinoussi F, Hurtrel B, Aubertin AM, Venet A, Mehtali M, Muchmore E and Michel P et al. (1994) Programmed cell death and AIDS: significance of T-cell apoptosis in pathogenic and nonpathogenic primate lentiviral infections. Proc. Natl. Acad. Sci. USA 91: 9431-9435

84. Buzyn A, Petit F, Ostankovitch M, Figueiredo S, Varet B, Guillet JG, Ameisen JC and Estaquier J (1999) Membrane-bound Fas (Apo-1/CD95) ligand on leukemic cells: a mechanism of tumor immune escape in leukemia patients. Blood 94: 3135-3140

85. Bergeron $\mathrm{A}$, Bonay M, Kambouchner M, Lecossier D, Riquet M, Soler $\mathrm{P}$, Hance A and Tazi A (1997) Cytokine patterns in tuberculous and sarcoid granulomas: correlations with histopathologic features of the granulomatous response. J. Immunol. 159: 3034-3043 